\title{
Latent postharvest pathogens of pome fruit and their management: from single measures to a systems intervention approach
}

\author{
Marcel Wenneker 1 - Bart P. H. J. Thomma
}

Accepted: 16 January 2020 /Published online: 21 January 2020

(C) The Author(s) 2020

\begin{abstract}
Postharvest diseases of pome fruit are typically caused by a wide diversity of fungal pathogens, and the list of confirmed causal agents is still growing. There is considerable knowledge on the epidemiology of wound pathogens, such as Botrytis cinerea and Penicillium expansum. In contrast, knowledge on the occurrence of the different postharvest diseases caused after latent (quiescent) infections during long-term storage and their epidemiology is limited. Well-known pathogens causing postharvest losses after latent infections are Neofabraea spp. and Colletotrichum spp., but in many cases the causal agents that occur in a specific region remain unknown and their control relies on the routine use of fungicide applications. However, due to the growing concern over the use of synthetic fungicides, alternative control measures are highly desired. Over the past years the use of physical treatments, natural compounds, and biocontrol agents have been investigated as alternatives. However, no single method has emerged that can robustly and reliably control postharvest diseases of pome fruit in practice. In this review it is argued to approach latent postharvest diseases as complex problems that require multiple interventions at different stages of the disease process in a systems
\end{abstract}

\footnotetext{
M. Wenneker $(\bowtie)$

Wageningen University and Research, Business Unit Field Crops, P.O. Box 200, 6670 AE Zetten, The Netherlands

e-mail: marcel.wenneker@wur.nl
}

B. P. H. J. Thomma

Laboratory of Phytopathology, Wageningen University,

P.O. Box 16, 6700 AA Wageningen, The Netherlands intervention approach for their control. Such approach requires a deep understanding of the epidemiology of the causal agents in the orchard, fruit defence mechanisms against pathogens, and the molecular biology of host-pathogen interactions in order to develop novel disease control methods in which the deployment of resistant cultivars can be a cornerstone.

Keywords Postharvest diseases · Fruit-fungal interaction · Pathogenicity · Quiescence · Control methods

\section{General introduction}

Apples and pears (pome fruit) are important deciduous fruit species cultivated on a worldwide scale. Mild and humid climatic conditions, such as those prevalent in North Western Europe, favour fungal diseases on pome fruit, such as apple scab (Venturia inequalis), brown spot of pear (Stemphylium vesicarium), European fruit tree canker (Neonectria ditissima), and postharvest fruit rots.

Production and storage of pome fruit in the Netherlands

Apple (Malus domestica) and pear (Pyrus communis) are important fruit crops that are cultivated in the Netherlands. The main apple cultivar is Elstar grown on $40 \%$ of the total apple production area, while the main pear cultivar is Conference grown on $75 \%$ of the pear production area (CBS 2016). After harvest, fruit are stored 
for up to 11 months under specific controlled atmosphere (CA) conditions, such as ultralow oxygen (ULO) and dynamic controlled atmosphere (DCA), depending on the cultivar and volume to be marketed (Thewes et al. 2015; Van Schaik and Verschoor 2003). However, as fruit are typically stored for extended periods of time, postharvest diseases have become a limiting factor of significant concern.

Postharvest diseases of pome fruit

Postharvest diseases of pome fruit result in significant economic losses during storage worldwide every year. They are typically caused by a variety of fungal pathogens, although also bacterial and oomycete postharvest pathogens can occasionally occur. Despite technological advances in postharvest handling of fresh fruit, postharvest fruit losses range from 5 to $20 \%$ with upwards of $50 \%$ on susceptible cultivars (Janisiewicz and Korsten 2002; Jones and Aldwinckle 1991; Jurick II et al. 2011). For example, bull's eye rot (Neofabraea spp.) is the main disease of stored apples in Poland, causing up to 30-40\% of postharvest losses on susceptible apple cultivars (Michalecka et al. 2016). Similarly, bull's eye rot and bitter rot (Colletotrichum spp.) have been reported to cause up to $30 \%$ decay during storage of organically grown apples in northern Germany (Maxin et al. 2014).

Postharvest diseases of apple and pear are caused by a range of fungal pathogens (Sutton 2014). Wounds caused by insects and birds, as well as by physical damage that is inflicted before or during harvest, are important entrance sites for pathogens such as Botrytis cinerea, Penicillium expansum and Monilinia fructigena, the causal agents of grey mould, blue mould, and brown rot, respectively (Snowdon 1990). These pathogens typically cause rapid decay of fruit in the pre- and postharvest stage. Fungicide applications shortly before harvest and careful handling of fruits during harvest are effective measures to significantly reduce losses by these wound pathogens.

However, another group of pathogens infects developing, unwounded fruits during the growing season. After infection these pathogens remain quiescent, i.e. without causing symptoms during the growing season. In epidemiology, there is a difference between latent and quiescent infections. Briefly, a latent infection is a nonsymptomatic infection, whereas a quiescent infection is an incipient visible infection (Jarvis 1994; Verhoeff 1974). This implies the quiescence is the passage from symptomless internal infections (i.e. a latent infection) to visible but non-expanding lesions, due for example to environmental or physiological and biochemical changes (De Silva et al. 2017; Prusky et al. 2013). In this review we use the term latent synonymously with quiescent. Thus, after several months in CA storage symptoms start to appear, when certain physiological or biochemical cues in the host are changed (Coates and Johnson 1997; Lattanzio et al. 2001). Examples of fungal pathogens causing postharvest losses are Neofabraea alba (Chen et al. 2016; Soto-Alvear et al. 2013), Neonectria ditissima (Weber and Dralle 2013), the Colletotrichum acutatum species complex (Spolti et al. 2012), Cadophora malorum (Sugar and Spotts 1992), Phytophthora spp., Alternaria spp., and Fusarium spp. (Sever et al. 2012). Moreover, novel latent postharvest pathogens are described continuously, such as Phacidium lacerum (Wiseman et al. 2016), Sphaeropsis pyriputrescens and Phacidiopycnis washingtonensis (Kim and Xiao 2008; Weber 2011; Xiao and Kim 2008). Postharvest pathogens are able to pass or overcome the natural defence systems that operate in fruit (Alkan et al. 2015). They infect through wounds, direct penetration of intact tissue, or colonization of natural openings such as lenticels, stems, and pedicels (Prusky and Lichter 2007). Fruit maturity has been implicated in the susceptibility of apples to particular fruit rot diseases. Brook (1977) observed that apples did not show symptoms of bitter rot caused by C. gloeosporioides until fruit were approaching maturity. Similarly, increasing maturity in apples resulted in higher incidences of bull's eye rot caused by Neofabraea alba (Edney 1964) and also blue mould caused by P. expansum (Vilanova et al. 2014). The increased disease incidence towards the end of a growing season has been hypothesized to be due to changes in the availability of natural openings in response to fruit maturity (Aguilar et al. 2017). For instance, during fruit maturation changes in mineral content but also environmental factors may affect the breakdown of lenticels (Turketti et al. 2012). Alternatively, the increased susceptibility could be due to fruit maturation-related degradation of phenolic compounds that inhibit fungal growth during fruit maturation (Edney 1964). Interestingly, a recent study of Everett et al. (2018) has shown that the incidence of infection of 'Royal Gala' apples by C. acutatum was related to temperature rather than to maturity of the fruit. However, in this case, only late in the 'Royal Gala' cultivation season the mean daily 
temperatures exceeded $15{ }^{\circ} \mathrm{C}$, so temperatures that are permissive for infection only occurred when fruit were more mature. Also high nitrogen $(\mathrm{N})$ content in fruit has been implicated in the incidence of bull's eye rot, blue mould and brown rot on apple fruit (Lysiak 2013; Sharples 1985), potentially due to weaker cell walls and thus greater sensitivity to fungal pectolytic enzymes (Bateman and Basham 1976).

Because of their complicated biology, which involves an enigmatic switch from a quiescent to a symptomatic stage, latent postharvest pathogens are poorly understood and their control is challenging. In this review we focus on latent postharvest pathogens that are responsible for late postharvest losses of pome fruit and discuss how these pathogens can be controlled.

\section{Specific latent postharvest pathogens}

As stated, a growing list of fungi is reported to be associated with latent postharvest fruit rots of pome fruit. In order to develop effective control strategies, it is necessary to assess which are the most important latent postharvest pathogens that occur in a specific region on the crop. Based on the current literature the economically most important latent postharvest pathogens in most apple and pear growing areas are Colletotrichum spp. and Neofabraea spp.

\section{Colletotrichum spp.}

Colletotrichum species are considered as major pathogens associated with pre- and postharvest fruit diseases (Alaniz et al. 2015; Cannon et al. 2012; Dean et al. 2012; Phoulivong et al. 2010). Apple bitter rot caused by Colletotrichum spp. is a widespread fruit disease occurring in most countries where apples are cultivated (Shi et al. 1996). C. acutatum species complex (SC) infections on apples in Europe are frequently reported with increasing numbers of recent reports from Belgium, England, Italy, France, Norway and Slovenia (Børve and Stensvand 2015; Grammen et al. 2019; Mari et al. 2012; Munda 2014; Munir et al. 2016; Nodet et al. 2016). Studies from Germany and Sweden describe postharvest losses of apple fruits of 10 and $25 \%$, respectively, by C. acutatum SC (Børve and Stensvand 2017; Weber and Palm 2010).

In warmer climates, C. acutatum $\mathrm{SC}$ infections lead to symptoms on apples during the summer growing period while the fruits are still on the trees. However, in cooler growing areas C. acutatum is more commonly observed as a latent storage pathogen (Everett et al. 2018). Disease symptoms of bitter rot are characterised by the development of small dark brown spots eventually expanding to light brown sunken lesions. Afterwards conidia are formed in acervuli concentrically in the centre of the lesion (Damm et al. 2012). All apple cultivars are susceptible to bitter rot, and in particular those belonging to the late-harvest group, such as Granny Smith, Pink Lady, and Fuji (Velho et al. 2015). It is considered that apple bitter rot has a higher destructive potential than other apple rots and can result in losses up to $50 \%$ at pre- and postharvest stages (Everett et al. 2015; Velho et al. 2015).

Besides Colletotrichum acutatum SC, also C. gloeosporioides SC has been implicated in bitter rot. In Japan, bitter rot is one of the most severe diseases in apple production in general (Yokosawa et al. 2017). In countries such as in Brazil (Crusius et al. 2002), USA (Shi et al. 1996; Gonzales et al. 2006), and New Zealand (Everett et al. 2015) both C. gloesporioides SC and species within the $C$. acutatum complex occur together.

Both the species complexes of $C$. acutatum and C. gloeosporioides are considered as hemibiotrophs. It is assumed that they first have a biotrophic infection stage in which they retrieve their nutrients from living plant cells, and this is followed by a necrotrophic stage in which they kill host tissue to obtain their nutrition (Peres et al. 2005). It is known that these fungal species overwinter on infected peach and blueberry buds and twigs, but on apple the source of inoculum is not obvious (Peres et al. 2005). Recently, a few studies of the aetiology and epidemiology on apples have been published (Børve and Stensvand 2013, 2017). Also, a disease cycle for $C$. acutatum SC infecting apples and causing bitter rot in New Zealand was proposed (Everett et al. 2018). In this particular case it is suggested that inoculum is most commonly rain-splashed from inoculum sources, such as decaying petals, twigs and infected fruitlets that have fallen to the ground since spring. Infection is proposed to occur after conidiospore deposition on fruit, leaves and buds if they formed, in the presence of sufficient moisture and temperatures above $15{ }^{\circ} \mathrm{C}$ when the spores germinate and form appressoria to establish quiescent infections (Peres et al. 2005). Infections of buds and leaves are symptomless, because symptoms are not observed on leaves on the tree in New Zealand and buds do not seem to be 
negatively affected in the following spring. In spring, buds open and the cycle can begin again (Everett et al. 2018).

The penetration and infection is well described for Colletotrichum spp. For instance, penetrating hyphae of Colletotrichum appressoria develop within the cuticle and uppermost epidermal cell layers of unripe fruit without eliciting visible host reactions, suggesting that fungal effectors that are secreted to support host colonization may interfere host response mechanisms (Giraldo and Valent 2013; Kleemann et al. 2012). The appressoria of Colletotrichum spp. are highly polarized cells from which a needle-like penetration hypha emerges in order to puncture the cuticle and epidermal cell wall (Howard and Valent 1996; Latunde-Dada 2001). At this stage, Colletotrichum is noted for its ability to maintain itself in an extended quiescent state until fruit ripening (Prusky et al. 2013).

Timely applications of fungicides are presumed to reduce infections of buds during summer, and in that way interrupt the disease cycle and could more effectively control the disease (Everett et al. 2015). This may provide a considerable improvement in reducing the number of applications over the currently recommended practice of calendar spraying throughout the season (Sutton 2014). Over the past few years, resistance of Colletotrichum spp. to the quinone-outside inhibitors (QoI) group of fungicides have appeared (Forcelini et al. 2018) and QoI resistant Colletotrichum isolates have been recovered from apples (Munir et al. 2016).

\section{Neofabraea spp.}

Bull's eye rot of apple and pear is an important postharvest disease, occurring in major fruit-growing areas of North America, Chile, Australia and Europe (Henriquez et al. 2004, 2008; Soto-Alvear et al. 2013; Spotts et al. 2009). The disease commonly occurs in most apple cultivars with an incidence of 10-20\%, and may exceed $40 \%$ in years that are favourable to pathogen infection (Cameldi et al. 2016; Soto-Alvear et al. 2013). In Europe, 'Golden Delicious' and several late maturing apple cultivars, such as Pink Lady, are particularly susceptible to the disease (Cameldi et al. 2016; Neri et al. 2009). Bull's eye lesions on apple and pear fruits are generally caused by Neofabraea species, with $N$. vagabunda (syn. $N$. alba) as the main causal agent. However, also $N$. malicorticis, $N$. perennans, and $N$. kienholzii have been described to cause the disease (Gariépy et al. 2005;
Michalecka et al. 2016; Pešicová et al. 2017; SotoAlvear et al. 2013; Spotts et al. 2009).

Besides symptoms on stored fruit, Neofabraea spp. cause cankers on branches or develop saprophytically on pruning stubs and dead tree branches (Henriquez et al. 2006; Verkley 1999). The pathogen spreads by asexual sporulation on fruit mummies and bark cankers (Spotts 1990; Weber 2012). Conidiospores are produced throughout the year, but the highest sporulation levels occur during autumn (Henriquez et al. 2006). Although rain splash is considered the principal way for conidial dispersal, conidia can also be splash-dispersed by over-tree irrigation practices (Grove et al. 1992). Infections typically occur in the orchard throughout the growing season, anytime between petal fall and harvest, when unripe fruits are penetrated through the lenticels. Fruit susceptibility increases gradually during the season (Aguilar et al. 2017; Cameldi et al. 2016; Spotts 1990). After infection, the pathogen arrests its growth and remains quiescent until the fruit reaches a certain stage of ripeness when it can invade fruit tissues. Typically, bull's eye rot symptoms appear only after 3-4 months in cold storage, and numerous lesions may develop on a single fruit (Neri et al. 2009). Fruit lesions are circular, flat to slightly sunken, brown and often with a lighter brown center (Snowdon 1990).

Current management practices to control Neofabraea spp. in the orchard include pruning of cankers from infected trees to minimize the build-up of inoculum during the fruit growing season, removal of fallen fruit and dead tree branches from the orchard floor, and reduced use of over-tree irrigation systems that may promote splash dispersal of conidia from sporulating cankers onto developing fruit (Creemers 2014). Furthermore, fungicide application is a common component of bull's eye rot management (Aguilar et al. 2018).

Postharvest pathogens of pome fruit in the Netherlands and their control

Postharvest disease caused by Colletotrichum spp. and Neofabraea spp. are generally not causing severe problems in the Netherlands, most likely because here the main apple cultivar Elstar and pear cultivar Conference are not susceptible to these pathogens. However, more susceptible apple cultivars, such as Pinova and Topaz, 
are frequently affected by Neofabraea spp. also in the Netherlands.

Until recently, it was unknown what the main causal agents of postharvest decay of pome fruit in the Netherlands were. In order to determine this, decayed apple and pear fruit were sampled from commercial CA storage facilities. In total, approximately 350 samples, derived from orchards with various apple and pear cultivars and from various production areas in the Netherlands, were analyzed between 2012 and 2018. These surveys revealed the presence of common postharvest pathogens, such as Botrytis cinerea and Neofabraea alba, but also a number of new and emerging postharvest pathogens, such as Fusarium avenaceum on pear and apple, Neonectria candida and Neofabraea kienholzii on pear, and Colletotrichum godetiae and Truncatella angustata on apple (Wenneker et al. 2016a, b, c, d, 2017a, b). In most cases these newly described postharvest pathogens were isolated at low incidences only. In contrast, two latent postharvest pathogens more frequently appeared: Cadophora luteoolivacea causing side rot on pears (Wenneker et al. 2016e), and Fibulorhizoctonia psychrophila as the causal agent of lenticel spot on apples and pears (Wenneker et al. 2017c). For both diseases incidences range from very low to nearly $100 \%$ of stored fruits. Thus, these latter two fungal species are presently considered as the most important postharvest pathogens on pome fruit in the Netherlands.

The use of synthetic fungicides is currently the main means to control side rot and lenticel spot diseases. However, despite the routine use of fungicide applications fruit infections during the orchard phase are a growing problem. This may be due to the use of noneffective chemicals, ineffective spray application technologies or inadequate timing of the applications. Basically, robust knowledge on how to control these diseases with fungicide applications is lacking and current management is largely practiced in an empirical fashion. This requires urgent attention in order to ensure the deposition of sufficient quantities of active ingredients on fruits for disease protection during the entire storage period. However, the growing public concern over the health and environmental risks associated with high levels of fungicide residues on fruits, as well as the development of fungicide resistance in fungal pathogens, has resulted in the urge for developing alternative methods for disease control (Wisniewski et al. 2016a).

\section{Alternatives to chemical fungicides for controlling postharvest diseases}

Over the past decades the use of physical treatments, natural compounds, and biocontrol agents have been investigated as alternatives for the use of fungicides for controlling postharvest diseases, including diseases caused by latent infections. More recently, the fruit microbiome is considered as an important factor for controlling latent postharvest diseases (Droby and Wisniewski 2018).

Physical treatments

Physical treatments, like hot water and hot air treatments, radio frequencies and microwaves, hypobaric and hyperbaric pressures and far ultraviolet radiation (UV-C light) are considered as promising control means to reduce or delay the development of postharvest pathogens (Maxin et al. 2012; Usall et al. 2016). In Europe hot water dips are used for organic apples (Maxin et al. 2012). However, there are several disadvantages of hot water dipping that include high investment costs, relatively low throughput, additional labor during harvest time, high running costs and negative $\mathrm{CO}_{2}$ footprint due to the energy requirement (Maxin et al. 2014). Consequently, hot water dipping is not implemented on larger scales in the fruit industry. As reduction in application time of the heat treatment could increase the interest in commercial use, research efforts have focused on short hot water treatments (rinsing) and expanding machine capacities (Maxin et al. 2012).

Radio frequency and microwave heating may provide effective alternative means to control postharvest diseases. The time required for microwave treatment is more favorable for commercial application, but the design and production cost for an equipment currently still obstructs its widespread application (Usall et al. 2016).

Among the remaining physical means, ultraviolet-C light (UV-C) treatment was considered to be interesting due to the simultaneous combination of direct activity against pathogens through germicidal effects on fungal spores with resistance induction through stimulation of defence mechanisms in several postharvest commodities including stone, pome, citrus fruit and table grapes (Nigro et al. 1998; Stevens et al. 1996; Valero et al. 2007; Wenneker et al. 2013). Although UV-C irradiation does not completely inhibit mycelial growth in vitro, a reduction in growth and sporulation was recorded for 
most tested fungal species (Wenneker et al. 2013). However, UV-C has a superficial effect only due to the limited penetrating capacities of the waves. Thus, the potential for controlling latent infections will eventually be limited. Also, control of wound infections is not possible due to shielding effects by pores and irregularities on the fruit surface (Lagunas-Solar et al. 2006). Hormetic UV-C treatment of apples induced resistance to postharvest diseases, although the effect was relatively low (Stevens et al. 1996).

Presently, short hypobaric and hyperbaric pre-storage treatments with low and high ambient air pressure, respectively, are considered as promising alternative treatments for postharvest disease control, although their use remains largely unexploited to date (Usall et al. 2016).

\section{Natural compounds}

The application of microbial and plant volatile organic compounds (VOCs) to control postharvest decay have recently been reviewed by Mari et al. (2016). It is shown that plant-produced volatiles, including aldehydes, alcohols, essential oils, isothiocyanates and microbial volatile organic compounds may prevent pathogenic infections in many horticultural commodities (Mari et al. 2011; Sivakumar and Bautista-Baños 2014). However, the introduction of natural compounds into practice is complicated due to the expense of registration and limited market for them as plant protection products. Also, there are concerns about possible residues in fruit, and negative effects on taste and smell of fruits (Mari et al. 2016).

\section{Biological control agents}

Biological control agents (BCA's) have been the focus of considerable research efforts (Droby et al. 2016; Janisiewicz and Jurick II 2017), and are used to developed strategies to control postharvest decays of fruits. Especially wound-invading necrotrophic pathogens turn out to be sensitive to biocontrol (Janisiewicz 1988; Janisiewicz 1998; Korsten et al. 1994; Wilson and Wisniewski 1989). The control is facilitated because the antagonists can be applied directly to the targeted area (fruit wounds) by a single application using existing systems such as drenches and line sprayers (Janisiewicz and Korsten 2002). In addition to control of fruit wound infections, biocontrol also has been demonstrated to be effective for stem infection on pears (Janisiewicz 2006).

Several modes of action have been suggested to explain the biocontrol activity of microbial antagonists. The competition for nutrients and a niche between the pathogen and the antagonist is still considered as the major mode of action by which microbial agents control pathogens causing postharvest decay (Droby et al. 1992; Ippolito and Nigro 2000; Jijakli et al. 2001). Other modes of actions comprise the production of antibiotics, direct parasitism, and possibly induced resistance by which the microbial antagonists suppress the activity of postharvest pathogens on fruits (El-Ghaouth et al. 2004; Janisiewicz et al. 2000).

Several microbial antagonists have been identified and artificially introduced on a variety of harvested commodities including citrus, pome, and stone fruits, and vegetables for control of postharvest diseases (Sharma et al. 2009). More specifically for pome fruits, the biocontrol potential of microbial antagonists was reported to control decay caused by Botrytis cinerea and Penicillium expansum by the bacterial antagonists Pseudomonas cepacia, P. syringae, and P. fluorescens (Janisiewicz et al. 1991; Mikani et al. 2008). Decay of apple was also controlled by antagonistic yeasts such as Candida sake (Teixidó et al. 1999; Usall et al. 2001), C. oleophila (Wisniewski et al. 1995), and C. saitona (El-Ghaouth et al. 1998).

The success of some of these microbial antagonists in laboratory studies and pilot tests resulted in the commercialization of bioproducts containing microbial antagonists for control of postharvest diseases of fruits. For apples such bioproducts comprise Bio-Save (active ingredient (a.i.) Pseudomonas syringae), Boni Protect (a.i. Aureobasidium pullulans), Candifruit (a.i. Candida sake), Nexy (a.i. C. oleophila), Pantovital (a.i. Pantoea agglomerans), Shemer (a.i. Metschnikowia fructicola) and Yield Plus (a.i. Cryptococcus albidus) (Janisiewicz and Jurick II 2017; Sharma et al. 2009). Nevertheless, the commercial deployment of postharvest biocontrol agents has met difficulties for widespread success, which has been attributed to various problems, including inconsistent performance, high cost relative to synthetic fungicides, registration hurdles, difficulties in mass production and formulation of the antagonist, and lack of industry acceptance (Droby et al. 2009; Droby et al. 2016). The limitations of biocontrol products may be addressed by enhancing the bio-efficacy of microbial antagonists through: (i) manipulations in the 
physical and chemical environment during storage, (ii) use of mixed cultures, (iii) addition of low doses of fungicides in the microbial cultures, (iv) addition of salt additives in the microbial cultures, (v) addition of nutrients and plant products in microbial cultures, (vi) use of the microbial cultures in association with physical treatments, and (vii) use of the microbial cultures with other approaches/additives (Janisiewicz 1996; Janisiewicz and Jurick II 2017; Sharma et al. 2009).

Thus far, research on biocontrol of postharvest diseases has mainly focused on identifying microorganisms that are antagonistic to wound pathogens and the effects of biocontrol agents on latent postharvest pathogens of pome fruit have hardy received attention in these studies (Droby et al. 2009; Sharma et al. 2009). Moreover, biocontrol relying on preventive mechanisms e.g. competition for limiting nutrients or space, which are effective in controlling fruit decays originating from wound infections, are not likely to succeed in this situation. Also, the strategy in most research studies published over the last few years has been to identify a BCA effective for a given pathogen, followed by testing its efficacy against other pathogens, often with limited success (Gava et al. 2018).

Currently, there is no specific biocontrol product available to control fruit decays originating from latent infections. According to Janisiewicz et al. (2011) this is due to the lack of appropriate methods for selecting effective biocontrol agents for controlling latent infections originating from appressoria and testing their effectiveness on fruit. Recently, they developed a novel approach based on a direct interaction of the isolated microorganisms with a pathogen (M. fructicola) latent infection structure in vitro and further screening of the selected potential antagonists for biocontrol effectiveness on fruit under laboratory conditions. The next step is to select those antagonists that are best adapted to conditions occurring during storage and handling of the fruit (Janisiewicz et al. 2011).

In addition to the development of novel biocontrol agents to prevent latent infections, a biocontrol agent (as well as a chemical compound) may be applied early in the season or even during the flowering stage. Therefore, application of biocontrol agents in the field during the growing season has been suggested (Ippolito and Nigro 2000; Lima et al. 1997; Lopes et al. 2015). However, knowledge on epidemiology of the causal agents of latent postharvest diseases is limited. Timing of application is complicated as the precise infection periods are often not known, may differ between the various pathogens, and infections may occur during the entire period from flowering until harvest.

The fruit microbiome

Microbial communities living on the surface of fruit have been the source of most of biocontrol agents (Janisiewicz 1987; Janisiewicz and Korsten 2002). They may directly influence pathogen development through antibiosis, parasitism or competition. The microbiota may also have an indirect role by stimulating plant defences. The commonly-used approach to identify novel biocontrol agents involves the identification of a single antagonist that can develop rapidly in wounded fruit tissue, thus preventing pathogens from becoming established. This approach, however, neglects interactions of antagonists with other microbes that occupy the same, or surrounding, niches as part of a microbial network and as a component of a complete biological system with the host (Droby et al. 2016).

Thus far, the overall diversity and composition of microbial communities on harvested produce, how they vary across produce types, and the factors that influence their composition after harvest and during storage, has been poorly studied (Droby and Wisniewski 2018). Recently, massive sequencing of PCR amplicons of specific barcode genes in amplicon metagenomics or metabarcoding approaches have revealed microbial diversities and relative quantities of community members in environmental samples (Abdelfattah et al. 2015; Massart et al. 2015). Such technology can similarly be used to characterize the composition of microbial communities on fruit, and also to identify strains considered as "helper microbial strains" or molecules involved in improving these direct or indirect effects against plant pathogens (Massart et al. 2015).

For example, Abdelfattah et al. (2016) demonstrated that the diversity of the fungal microflora of harvested apples differed significantly between fruit parts. Whereas Penicillium was dominant in peel samples, Alternaria was dominant in calyx- and stem-end samples. Niem et al. (2007) showed that differing susceptibilities of cv. Red Delicious and cv. Golden Delicious to core rot decay were not determined by the initial colonization of the blossom by the causal agent Alternaria alternata, but rather by the capability of the pathogen to colonize the host seed locule of the susceptible fruits. This type of information needs to be considered when designing 
biocontrol systems for the management of postharvest diseases. For mango it was recently shown based on microbiome comparisons of stem ends that are resistant and susceptible to stem end rot in red and green fruit, respectively, that fungal and bacterial community change with fruit peel colour, storage duration, and storage temperature (Diskin et al. 2017).

Currently, Neofabraea spp. infection levels on apples at the time of harvest and the microbial dynamics on the apple skin during storage are characterized using a metagenomics approach (Bühlmann, pers. comm.). Ultimately, this type of research may lead to the synthetic design of microbial communities that can be used for postharvest disease management. Maintaining the right balance and diversity inside the consortium before and after its application, however, may be difficult. Regulatory difficulties in registering a consortium, composed of multiple microorganisms, as a biocontrol product may also become a problem.

\section{A systems intervention approach}

Some of the alternative methods to chemical fungicides for controlling latent postharvest diseases seem to hold promise for future application if the remaining challenges are met. After all, significant gaps still exist between the basic research that led to the discovery of these methods and their implementation under commercially relevant conditions. In order for such method to be applicable in practice, it must perform effectively and reliably, and be profitable to the company that has invested in its development, registration, and marketing. The results of the search for alternatives to chemical fungicides over the past thirty years show that, although several novel approaches have been identified as potential alternatives, no single method has emerged to robustly and reliably control postharvest diseases of pome fruit in practice. Thus, it may be advisable to move the focus from finding a single 'silver bullet' intervention that can be used to effectively control disease to composing and integrated systems approach by selecting the right set of control measures from a wide array of alternatives (Wisniewski et al. 2016a).

Already many recent research efforts are focussing on developing integrated control with biological control as a central pillar in combination with other compatible treatment(s), or combinations of alternative treatments (see reviews by Di Francesco and Mari 2014;
Janisiewicz and Conway 2010; Palou et al. 2016; Romanazzi et al. 2016b; Usall et al. 2015). In this respect, this approach is well represented by the "hurdle concept" that was developed for apples (Janisiewicz 2008, 2013), which follows the original idea that was originally developed for food preservation (Leistner 2000). The "hurdle concept" explores the use of mild treatments that collectively maintain fruit quality and lower the incidence of postharvest decay (Palou et al. 2016). In the hurdle concept, each additional treatment reduces the incidence/severity of the decay by a certain percentage, and eventually results in the pathogen not being able to overcome the final hurdle, resulting in control of the fruit decay (Janisiewicz and Jurick II 2017). This view implies that latent postharvest diseases are complex problems that require multiple interventions at different stages of the disease process. Consequently, understanding the epidemiology of latent postharvest pathogens in the orchard, fruit defence mechanisms against pathogens, and the molecular biology of their interactions is required in order to develop novel integrated disease control methods (Droby et al. 2009; Tian et al. 2016).

\section{The inoculum pressure of latent postharvest pathogens}

There is considerable knowledge on the epidemiology of typical wound pathogens such as $P$. expansum. However, knowledge on epidemiology of the causal agents of latent postharvest diseases is limited. The control of the complex diversity of postharvest pathogens in orchards is difficult. The precise infection periods are often not known and may differ between the various pathogens, and is often complicated because infections may occur during the entire period from flowering until harvest.

Recently, Köhl et al. (2018) showed that both N. alba and C. luteo-olivacea were consistently detected in leaf litter of apple and pear and in necrotic tissues of dead weeds and grasses, and in many cases high concentrations of the pathogens were quantified. These are important new findings that may help to better understand how complex population dynamics of these necrotrophic pathogens depend on the availability of various necrotic host and non-host tissues for survival and multiplication. However, further research is still needed to understand: (i) the relationships between the 
accumulation of pathogen inoculum on the various substrates over time, (ii) the relative importance of different substrates as inoculum sources for fruit infections, and (iii) infection periods on developing fruits in the orchard. Eventually, this knowledge can be used for the development of sanitation measures (Holb 2006; Llorente et al. 2010), or measures to stimulate beneficial microbiome inhabitants on those substrates that can antagonize pathogen colonization, survival and sporulation (Carisse and Rolland 2004; Llorente et al. 2006, 2010; Rossi and Pattori 2009).

\section{The quiescent stage of postharvest pathogens}

The quiescent phase, in this review also called latent phase, is a dynamic equilibrium among host, pathogen, and environment, which does not result in any visible symptoms on the host (Jarvis 1994; Prusky et al. 2013). During this stage, the fungal pathogens reside in the cuticular wax or in the intercellular space until the fruits ripen (Adaskaveg et al. 2000; Prins et al. 2000; Prusky et al. 1981). Apparently, at a particular moment physiological and biochemical responses of the host trigger changes in that equilibrium that activate the pathogen that is kept at a low metabolic level during the quiescent stage to activate pathogenicity mechanisms, resulting in active parasitic development in the host tissues (Prusky 1996). It has been proposed that the termination of the quiescent stage is the result of: (i) induced accessibility of disassembled cell wall substrates during fruit softening and ethylene induction; (ii) a decline in preformed antifungal compounds, such as polyphenols, phytoalexins, and other fungitoxic substances; (iii) a decline in inducible host-defence responses; and (iv) more favourable $\mathrm{pH}$ conditions in the host tissue. The $\mathrm{pH}$ in the fruit may change either naturally during fruit ripening or through induction by the pathogen that secretes $\mathrm{pH}$ modulators such as ammonia and organic acids as one of the first waves in their attack (Prusky et al. 2013; Yakoby et al. 2000). Both increases and decreases of ambient $\mathrm{pH}$, for instance by secretion of ammonia and organic acids, respectively, have been recorded depending on pathogen and host characteristics (Alkan et al. 2013). For example, Monilinia fruticola acidifies the ambient $\mathrm{pH}$ by the secretion of gluconic acid (De Cal et al. 2013), while Botrytis cinerea (Manteau et al. 2003) and Sclerotinia sclerotiorum (Cessna et al. 2000) secrete oxalic acid to acidify the $\mathrm{pH}$ while enhancing their polygalacturonase gene expression and other cell-walldegrading enzymes involved in tissue maceration (Misaghi 1982; Prusky and Lichter 2007). The produced endopolygalacturonases and pectin esterases may cause cell wall maceration and death of affected host cells (Paynter and Jen 1975). In contrast, Colletotrichum spp. were found to alkalinize the infection court by the secretion of ammonia to stimulate pathogenicity and necrotrophic colonization through the activation of host NADPH oxidases to generate reactive oxygen species, thereby accelerating host cell death (Miyara et al. 2010; Prusky et al. 2001).

Although not much is known for latent postharvest pathogens specifically, recently a $\mathrm{pH}$ increase was recorded in apple tissue infected by $N$. vagabunda (Cameldi et al. 2017). However, further research is necessary to clarify the nature and the origin of the alkalizing compounds and to understand the effects of the $\mathrm{pH}$ modulation on $N$. vagabunda pathogenicity.

\section{Plant and fruit defence mechanisms against postharvest pathogens}

Plants have an innate immune system that comprises a wide variety of constitutive and inducible defence mechanisms to protect themselves against pests and pathogens (Cook et al. 2015; De Wit 2007; Tian et al. 2016). Constitutive or preformed defences include physical barriers such as cell walls and epidermal cuticles, but also chemicals such are antimicrobial phytoanticipins and some pathogenesis-related (PR) proteins (Van Loon et al. 2006). In addition to these preformed barriers, plant cells have the ability to detect invading pathogens and respond with inducible defences (Cook et al. 2015; De Wit 2007). These can be triggered when plant cells recognize microbe-associated molecular patterns (MAMPs), including structural proteins, lipopolysaccharides, and cell wall components commonly found in microbes, through a set of cell surface receptors, also referred to as pattern recognition receptors (Nürnberger et al. 2004) or invasion pattern receptors (Cook et al. 2015). In a study focused on tomato fruit defence responses against C. gloeosporioides, it was shown that the expression of several fruit genes was induced even before appressorial penetration. Such genes included PAMP receptors and genes related to fatty acid biosynthesis, 
elongation, and the synthesis of cutin and waxes (Alkan et al. 2015).

Upon recognition, various defence responses are induced such as cell wall alterations, deposition of callose and the accumulation of PR proteins that include chitinases, glucanases and proteases that all negatively affect microbial colonization (Van Loon et al. 2006). Typically, also an oxidative burst occurs that involves the release of highly reactive oxygen molecules that damage the cells of invading organisms, cross-links host cell-wall components and acts as a signalling molecule to further enhance host immunity (Pitzschke et al. 2006).

Compatible pathogens can overcome the activation of host immunity by the secretion of effectors that perturb such responses (Kleemann et al. 2012; Weiberg et al. 2013; Zhang et al. 2014). Thus, pathogen effectors are crucial molecules for disease establishment (Rovenich et al. 2014). However, in turn plants have evolved receptors to recognize effectors or effector-mediated perturbations of host targets (Chisholm et al. 2006; Jones and Dangl 2006). These receptors may reside on the cell surface, but also inside the cytoplasm to detect (the activity of) cytoplasmically-delivered pathogen effectors (Cook et al. 2015). Often, the recognition of effectors has been associated with the occurrence of a hypersensitive response (HR); a localized programmed cell death response that may limit pathogen access to water and nutrients, and thus block further growth of the pathogen (De Wit 2007). However, necrotrophic pathogens may actually benefit from such cell death response, and have evolved in some cases to deliberately activate this host immune response to their benefit (Cook et al. 2015; Lorang et al. 2012).

In tissues that are distal from the infection site, plants are protected by so-called systemic acquired resistance (SAR) (Grant and Lamb 2006). SAR is effective against a broad range of pathogens and is dependent on various plant hormones, including salicylic acid (SA), jasmonic acid (JA), and ethylene (ET) (Grant and Lamb 2006). More recently, however, also various other hormones, such as auxin, abscisic acid (ABA), cytokinins (CKs), and brassinosteroids have been implicated in the activation of defence responses (Robert-Seilaniantz et al. 2011). SAR requires the signal molecule SA and is associated with accumulation of pathogenesis-related (PR) proteins (Durrant and Dong 2004; Terry and Joyce 2004).

\section{Induced resistance against postharvest pathogens of fruits}

A large amount of data has been generated related to priming of host plant defences and induce resistance during postharvest of fruits and vegetables (Janisiewicz and Jurick II 2017; Romanazzi et al. 2016a). The elicitation of host defences may be achieved by: (i) biocontrol agents, (ii) physical means (such as ultraviolet-C (UV-C) light, heat, hypobaric and hyperbaric treatments), (iii) natural and synthetic chemicals (such as phytohormones and chemical elicitors, salicylic acid, benzothiadiazole), (iv) biological elicitors (such as harpin and chitosan), (v) disinfecting agents (such as ozone, electrolyzed water, ethanol), and (vi) microbial and plant volatile organic compounds (VOCs) (Romanazzi et al. 2016a). However, there are a number of weaker points linked to the application of strategies based on induced resistance, such as possible inconsistent results or difficulties in their implementation in packinghouse practices. Moreover, to correctly induce resistance in fruits, it is necessary to know and understand the host-microbe interactions, and the effects on postharvest physiology and handling of the different fruits (Da Rocha and Hammerschmidt 2005; Tian et al. 2016).

\section{Breeding for resistant cultivars to postharvest diseases}

In general, fruit breeding objectives include high fruit quality, good agronomic performance and sometimes a durable disease resistance. In the latter case, in apple breeding mainly focussing on apple scab (Venturia inaequalis), fire blight (Erwinia amylovora), and powdery mildew (Podosphaera leucotricha) (Baumgartner et al. 2015). However, the success of newly developed disease resistant apple varieties is largely dependent on their fruit quality (Baumgartner et al. 2015). It should be emphasized that classic pome fruit breeding is a longterm and labor-intensive approach. The first fruits can usually be expected at the earliest in the fourth year after crossing. However, usually the first fruit quality selection step is carried out at the fifth to the seventh year after crossing. Currently, cultivated apples have often no resistance to fungi causing fruit decay as breeders seldom evaluate for resistance to postharvest diseases 
(Ahmadi-Afzadi et al. 2013; Janisiewicz et al. 2008; Volk et al. 2015).

Fruit cultivars may show a large variation in susceptibility to (latent) postharvest diseases (Tian et al. 2016), as was demonstrated among apple cultivars for bull's eye rot caused by Neofabraea spp. (Blazek et al. 2007; Hortova et al. 2014; Soto-Alvear et al. 2013) and for Colletotrichum spp. (Biggs and Miller 2001; Grammen et al. 2019). Unravelling resistance mechanisms in fruits can be very helpful to make progress in breeding programs.

A number of new methods that allow a more precise selection of tree and fruit characters in breeding programs were developed in recent years (Laurens et al. 2018). For instance, marker assisted selection (MAS) facilitates the selection of novel cultivars in a shortened period for evaluation. Patocchi et al. (2005) developed a strategy called genome scanning approach (GSA) for traits that are primarily controlled by single major genes. This method can be used to identify linked molecular markers without generating a complete genetic map. For traits controlled by multiple genes, the quantitative trait loci (QTL) mapping is generally applied (Tian et al. 2016; Wisniewski et al. 2016b). In peach breeding programs, Pacheco et al. (2014) and Martínez-García et al. (2013) have identified QTLs for brown rot response traits, while preliminary results from apple breeding programs have identified QTLs for blue mould resistance in Malus sieversii (Norelli et al. 2014) and a mapping population of 'Royal Gala' $\times M$. sieversii PI613981 (Wisniewski et al. 2016b).

In order to understand mechanisms involved in apple resistance to postharvest pathogens an approach involving temporal and spatial regulation of the transcriptome, proteome and metabolome combined with pathological analysis must be undertaken (Abdelfattah et al. 2015, 2016; Prusky et al. 2013). In this respect, sequencing of the genome of Colletotrichum species and transcriptome analysis of fungal-fruit interactions has revealed genes and key enzymes that are involved in the biosynthesis of fungal secondary metabolites that are important for pathogenicity and fruit defence responses (Alkan et al. 2015; Moraga et al. 2018). Nevertheless, typically, annotation processes and gene functional analyses are tedious and complicated. However, significant progress has been made in the determination of transcriptomic and proteomic factors that may lead to resistance in cultivated apples (Buron-Moles et al. 2015a, b; Vilanova et al. 2014), and several studies have provided data on genetically determined levels of resistance to $P$. expansum in apple cultivars (Ahmadi-Afzadi 2015; Tahir et al. 2015), and wild apples (Janisiewicz et al. 2016; Norelli et al. 2014).

Recently, a number of fruit crop genomes has been sequenced, including those of grapevine (Jaillon et al. 2007), apple (Velasco et al. 2010), banana (D’Hont et al. 2012), citrus (Xu et al. 2013), peach (Verde et al. 2013), and pear (Chagné et al. 2014). Also, the genomes of several postharvest pathogens have been sequenced, including those of $B$. cinerea (Amselem et al. 2011), several species of Alternaria (Dang et al. 2015), Colletotrichum (Gan et al. 2013), P. expansum and P. italicum (Ballester et al. 2015; Li et al. 2015). The genetic information that has been disclosed by these projects will provide insights in the virulence factors of these important postharvest pathogens, which can again be used in breeding and selection programs. In addition, genome-editing technologies involving CRISPR/Cas9 (Hsu et al. 2014) may be used to manipulate molecular regulators and edit promoters of apple fruit defence genes to enhance decay resistance in apple cultivars (Janisiewicz and Jurick II 2017). However, first of all, this requires a deeper knowledge of the fruit-pathogen-environment interactions at the physiological, biochemical and molecular level. Considering that combining plant genomics with classical breeding is a challenge for molecular biologists as well as for traditional breeders, an increased understanding of the basis of effective resistance mechanisms against the causal agents of postharvest pathogens is required. Eventually, such resistance mechanisms can be introduced into breeding programs to obtain postharvest disease resistant cultivars.

\section{Concluding remarks and future perspectives}

Losses due to the postharvest decay of pome fruits still represent a major concern from an economic point of view. However, it should be realized that fruit decay is a natural process to release seeds from mature fruit in order to start a new generation of the plant genotype. Currently, chemical fungicides represent the main tool for controlling the major postharvest pathogens as well as the deployment of optimal storage conditions. Interestingly, the synthetic cyclic olefin 1methylcyclopropene (1-MCP) that blocks ethylene receptors and that is used to extend fruit firmness during 
storage and marketing (Köpcke 2015) has also been shown to delay of onset of storage rots (McArtney et al. 2011) such as bull's eye rot on pears (Spotts et al. 2007) and on apples (Maxin and Weber 2011; Cameldi et al. 2016). Due to the growing concern over the use of synthetic fungicides, alternative measures to control postharvest diseases are sought. However, most of the alternative treatments developed so far have limitations that impede their effectiveness as single treatments. Combining different treatments within an integrated latent postharvest disease management strategy needs further development. Such integrated control methods should focus on reduction of the inoculum pressure of latent postharvest pathogens, interference of the typical latent stage of late postharvest pathogens and maximum exploitation of the plant's own immune system.

\section{Electronic supplementary material}

Ethical statements This article does not contain any studies with human participation or animals performed by any of the authors.

Conflicts of interest The authors declare that no known conflicts of interests exist.

Open Access This article is licensed under a Creative Commons Attribution 4.0 International License, which permits use, sharing, adaptation, distribution and reproduction in any medium or format, as long as you give appropriate credit to the original author(s) and the source, provide a link to the Creative Commons licence, and indicate if changes were made. The images or other third party material in this article are included in the article's Creative Commons licence, unless indicated otherwise in a credit line to the material. If material is not included in the article's Creative Commons licence and your intended use is not permitted by statutory regulation or exceeds the permitted use, you will need to obtain permission directly from the copyright holder. To view a copy of this licence, visit http://creativecommons.org/licenses/by/4.0/.

\section{References}

Abdelfattah, A., Nicosia, M. G. L. D., Cacciola, S. O., Droby, S., \& Schena, L. (2015). Metabarcoding analysis of fungal diversity in the phyllosphere and carposphere of olive (Olea europaea). PLoS One, 10, e0131069.

Abdelfattah, A., Wisniewski, M., Droby, S., \& Schena, L. (2016). Spatial and compositional variation in the fungal communities of organic and conventionally grown apple fruit at the consumer point-of-purchase. Horticulture Research, 3, 16047. https://doi.org/10.1038/hortres.2016.47.
Adaskaveg, J. E., Forster, H., \& Thompson, D. F. (2000). Identification and etiology of visible quiescent infections of Monilinia fructicola and Botrytis cinerea in sweet cherry fruit. Plant Disease, 84, 328-333.

Aguilar, C. G., Mazzola, M., \& Xiao, C. L. (2017). Timing of apple fruit infection by Neofabraea perennans and Neofabraea kienholzii in relation to bull's-eye rot development in stored apple fruit. Plant Disease, 101, 800-806.

Aguilar, C. G., Mazzola, M., \& Xiao, C. L. (2018). Control of bull's-eye rot of apple caused by Neofabraea perennans and Neofabraea kienholzii using pre- and postharvest fungicides. Plant Disease, 102, 905-910.

Ahmadi-Afzadi, M. (2015). Genetic variation in resistance to fungal storage diseases in apple. Dissertation Alnarp: Sveriges lantbruksuniv., Acta Universitatis agriculturae Sueciae, 1652-6880, 2015:18.

Ahmadi-Afzadi, M., Tahir, I., \& Nybom, H. (2013). Impact of harvesting time and fruit firmness on the tolerance to fungal storage diseases in an apple germplasm collection. Postharvest Biology and Technology, 82, 51-58.

Alaniz, S., Hernandez, L., \& Mondino, P. (2015). Colletotrichum fructicola is the dominant and one of the most aggressive species causing bitter rot of apple in Uruguay. Tropical Plant Pathology, 40, 265-274.

Alkan, N., Espeso, E. A., \& Prusky, D. (2013). Virulence regulation of phytopathogenic fungi by $\mathrm{pH}$. Antioxidants \& Redox Signaling, 19, 1012-1025.

Alkan, N., Friedlander, G., Ment, D., Prusky, D., \& Fluhr, R. (2015). Simultaneous transcriptome analysis of Colletotrichum gloeosporioides and tomato fruit pathosystem reveals novel fungal pathogenicity and fruit defense strategies. New Phytologist, 205, 801-815.

Amselem, J., Cuomo, C. A., van Kan, J. A., Viaud, M., Benito, E. P., Couloux, A., et al. (2011). Genomic analysis of the necrotrophic fungal pathogens Sclerotinia sclerotiorum and Botrytis cinerea. PLoS Genetics, 7, e1002230.

Ballester, A. R., Marcet-Houben, M., Levin, E., Sela, N., SelmaLázaro, C., Carmona, L., Wisniewski, M., Droby, S., González-Candelas, L., \& Gabaldón, T. (2015). Genome transcriptome, and functional analyses of Penicillium expansum provide new insights into secondary metabolism and pathogenicity. Molecular Plant-Microbe Interactions, 28, 232-248.

Bateman, D., \& Basham, H. G. (1976). Degradation of plant cell walls and membranes by microbial enzymes. Encyclopedia of Plant Physiology New Series, 4, 316-355.

Baumgartner, I. O., Patocchi, A., Frey, J. E., Peil, A., \& Kellerhals, M. (2015). Breeding elite lines of apple carrying pyramided homozygous resistance genes against apple scab and resistance against powdery mildew and fire blight. Plant Molecular Biology Reporter, 33, 1573-1583.

Biggs, A. R., \& Miller, S. S. (2001). Relative susceptibility of selected apple cultivars to Colletotrichum acutatum. Plant Disease, 85, 657-660.

Blazek, J., Opatova, H., Golias, J., \& Homutova, I. (2007). Ideotype of apple with resistance to storage diseases. HortiScience, 34, 108-114.

Børve, J., \& Stensvand, A. (2013). Incidence of Colletotrichum acutatum on apple fruits and possible sources of inoculum. IOBC-WPRS Bulletin, 91, 385-388. 
Børve, J., \& Stensvand, A. (2015). Colletotrichum acutatum on apple in Norway. IOBC-WPRS Bulletin, 110, 151-157.

Børve, J., \& Stensvand, A. (2017). Colletotrichum acutatum occurs asymptomatically on apple leaves. European Journal of Plant Pathology, 147, 943-948.

Brook, P. J. (1977). Glomerella cingulata and bitter rot of apple. New Zealand Journal of Agricultural Research, 20, 547-555.

Buron-Moles, G., Torres, R., Teixidó, N., Usall, J., Vilanova, L., \& Viñas, I. (2015a). Characterisation of $\mathrm{H}_{2} \mathrm{O}_{2}$ production to study compatible and non-host pathogen interactions in orange and apple fruit at different maturity stages. Postharvest Biology and Technology, 99, 27-36.

Buron-Moles, G., Wisniewski, M., Viñas, I., Teixidó, N., Usall, J., Droby, S., \& Torres, R. (2015b). Characterizing the proteome and oxi-proteome of apple in response to a host (Penicillium expansum) and a non-host (Penicillium digitatum) pathogen. Journal of Proteomics, 114, 136-151.

Cameldi, I., Neri, F., Ventrucci, D., Ceredi, G., Muzzi, E., \& Mari, M. (2016). Influence of harvest date on bull's eye rot of 'Cripps pink' apples and control chemical strategies. Plant Disease, 100, 2287-2293.

Cameldi, I., Neri, F., Menghini, M., Pirondi, A., Nanni, I. M., Collina, M., \& Mari, M. (2017). Characterization of Neofabraea vagabunda isolates causing apple bull's eye rot in Italy (Emilia-Romagna region). Plant Pathology, 66, 1432-1444.

Cannon, P. F., Damm, U., Johnston, P. R., \& Weir, B. S. (2012). Colletotrichum - Current status and future directions. Studies in Mycology, 73, 181-213.

Carisse, O., \& Rolland, D. (2004). Effect of timing of application of the biological control agent Microsphaeropsis ochracea on the production and ejection pattern of ascospores by Venturia inaequalis. Phytopathology, 94, 1305-1314.

CBS. (2016). Statistics Netherlands. http://www.cbs.nl/enGB/menu/home/default.htm.

Cessna, S. G., Sears, V. E., Dickman, M. B., \& Low, P. S. (2000). Oxalic acid, a pathogenicity factor for Sclerotinia sclerotiorum, suppresses the oxidative burst of the host plant. The Plant Cell, 12, 2191-2199.

Chagné, D., Crowhurst, R. N., Pindo, M., Thrimawithana, A., Deng, C., Ireland, H., et al. (2014). The draft genome sequence of European pear (Pyrus communis L. 'Bartlett'). PLoS One, 9, e92644.

Chen, C., Verkley, G. J. M., Sun, G., Groenewald, J. Z., \& Crous, P. W. (2016). Redefining common endophytes and plant pathogens in Neofabraea, Pezicula, and related genera. Fungal Biology, 120, 1291-1322.

Chisholm, S. T., Coaker, G., Day, B., \& Staskawicz, B. J. (2006). Host-microbe interactions: Shaping the evolution of the plant immune response. Cell, 124, 803-814.

Coates, L., \& Johnson, G. (1997). Postharvest diseases of fruit and stored vegetables. In P. Pathogens, D. J. F. Brown, \& H. J. Ogle (Eds.), University of new England Printery (pp. 533547). NSW: Armidale.

Cook, D. E., Mesarich, C. H., \& Thomma, B. P. H. J. (2015). Understanding plant immunity as a surveillance system to detect invasion. Annual Review of Phytopathology, 53, 541-563.

Creemers, P. (2014). Anthracnose canker and perennial canker. In T. B. Sutton, H. S. Aldwinckle, A. M. Agnello, \& J. F.
Walgenbach (Eds.), Compendium of apple and pear diseases and pests (2nd ed., pp. 51-53). St. Paul: APS Press.

Crusius, L. U., Forcelini, C. A., Sanhueza, R. M. V., \& Fernandes, J. M. C. (2002). Epidemiology of apple leaf spot. Fitopatologia Brasileira, 27, 65-70.

D’Hont, A., Denoeud, F., Aury, J.-M., Baurens, F.-C., Carreel, F., Garsmeur, O., Noel, B., Bocs, S., Droc, G., \& Rouard, M. (2012). The banana (Musa acuminata) genome and the evolution of monocotyledonous plants. Nature, 488, 213-217.

Da Rocha, A., \& Hammerschmidt, R. (2005). History and perspectives on the use of disease resistance inducers in horticultural crops. HortTechnology, 15, 518-529.

Damm, U., Cannon, P. F., Woudenberg, J. H., \& Crous, P. W. (2012). The Colletotrichum acutatum species complex. Studies in Mycology, 73, 37-113.

Dang, H. X., Pryor, B., Peever, T., \& Lawrence, C. B. (2015). The Alternaria genomes database: A comprehensive resource for a fungal genus comprised of saprophytes, plant pathogens, and allergenic species. BMC Genomics, 16, 239.

De Cal, A., Sandín-España, P., Martinez, F., Egüen, B., ChienMing, C., Lee, M. H., Melgareja, P., \& Prusky, D. (2013). The role of gluconic acid and $\mathrm{pH}$ modulation in virulence of Monilinia fructicola on peach fruit. Postharvest Biology and Technology, 86, 418-423.

De Silva, D. D., Crous, P. W., Ades, P. K., Hyde, K. D., \& Taylor, P. W. J. (2017). Life styles of Colletotrichum species and implications for plant biosecurity. Fungal Biology Reviews, 31, 155-168.

De Wit, P. J. G. M. (2007). How plants recognize pathogens and defend themselves. Cellular and Molecular Life Sciences, 64, 2726-2732.

Dean, R., Van Kan, J. A. L., Pretorius, Z. A., Hammond-Kosack, K. E., \& Di Pietro, A. (2012). The top 10 fungal pathogens in molecular plant pathology. Molecular Plant Pathology, 13, 414-430.

Di Francesco, A., \& Mari, M. (2014). Use of biocontrol agents in combination with physical and chemical treatments: Efficacy assessment. Stewart Postharvest Review, 10, 1-4.

Diskin, S., Feygenberg, O., Maurer, D., Droby, S., Prusky, D., \& Alkan, N. (2017). Microbiome alterations are correlated with occurrence of postharvest stem-end rot in mango fruit. Phytobiomes, 1, 117-127.

Droby, S., \& Wisniewski, M. (2018). The fruit microbiome: A new frontier for postharvest biocontrol and postharvest biology. Postharvest Biology and Technology, 140, 107-112.

Droby, S., Chalutz, E., Wilson, C. L., \& Wisniewski, M. E. (1992). Biological control of postharvest diseases: A promising alternative to the use of synthetic fungicides. Phytoparasitica, 20, 1495-1503.

Droby, S., Wisniewski, M., Macarisin, D., \& Wilson, C. (2009). Twenty years of postharvest biocontrol research: Is it time for a new paradigm? Postharvest Biology and Technology, 52, 137-145.

Droby, S., Wisniewski, M., Teixidó, N., Sparado, D., \& Jijakli, M. H. (2016). The science, development, and commercialization of postharvest biocontrol products. Postharvest Biology and Technology, 122, 22-29.

Durrant, W., \& Dong, X. (2004). Systemic acquired resistance. Annual Review of Phytopathology, 42, 185-209. 
Edney, K. L. (1964). Some factors affecting the rotting of stored apples by Gloeosporium spp. Annals of Applied Biology, 53, 119-127.

El-Ghaouth, A., Wilson, C. L., \& Wisniewski, M. E. (1998). Untrastructural and cytochemical aspects of biocontrol activity of Candida saitona in apple fruit. Phytopathology, 88, 282-291.

El-Ghaouth, A., Wilson, C. L., \& Wisniewski, M. E. (2004). Biologically based alternatives to synthetic fungicides for the postharvest diseases of fruit and vegetables. In S. A. M. H. Naqvi (Ed.), Diseases of fruit and vegetables (Vol. 2, pp. 511-535). Dordrecht: Kluwer Academic Publishers.

Everett, K. R., Pushparajah, I. P. S., Taylor, J. T., TimudoTorrevilla, O. E., Spiers, T. M., Chee, A. A., et al. (2015). Evaluation of fungicides for control of bitter and sprinkler rots on apple fruit. New Zealand Plant Protection, 68, 264-274.

Everett, K. R., Pushparajah, I. P. S., Timudo, O. E., Chee, A. A., Scheper, R. W. A., Shaw, P. W., et al. (2018). Infection criteria, inoculum sources and splash dispersal pattern of Colletotrichum acutatum causing bitter rot of apple in New Zealand. European Journal of Plant Pathology, 152, 367-383.

Forcelini, B. B., Rebello, C. S., Wang, N.-Y., \& Peres, N. A. (2018). Fitness, competitive ability, and mutation stability of isolates of Colletotrichum acutatum from strawberry resistant to QoI fungicides. Phytopathology, 108, 462-468.

Gan, P., Ikeda, K., Irieda, H., Narusaka, M., O'Connell, R. J., Narusaka, Y., Takano, Y., Kubo, Y., \& Shirasu, K. (2013). Comparative genomic and transcriptomic analyses reveal the hemibiotrophic stage shift of Colletotrichum fungi. New Phytologist, 197, 1236-1249.

Gariépy, T. D., Rahe, J. E., Levesque, C. A., Spotts, R. A., Sugar, D. L., \& Henriquez, J. L. (2005). Neofabraea species associated with bull's-eye rot and cankers of apple and pear in the Pacific northwest. Canadian Journal of Plant Pathology, 27, $118-124$

Gava, C. A. T., de Castro, A. P. C., Pereira, C. A., \& FernandesJúnior, P. I. (2018). Isolation of fruit colonizer yeasts and screening against mango decay caused by multiple pathogens. Biological Control, 117, 137-146.

Giraldo, M. C., \& Valent, B. (2013). Filamentous plant pathogen effectors in action. Nature Reviews Microbiology, 11, 800-814.

Gonzales, E., Sutton, T. B., \& Correll, J. C. (2006). Clarification of the etiology of Glomerella leaf spot and bitter rot of apple caused by Colletotrichum spp. based on morphology and genetic, molecular, and pathogenicity tests. Phytopathology, 96, 982-992.

Grammen, A., Wenneker, M., Van Campenhout, J., Pham, K. T. K., Van Hemelrijck, W., Bylemans, D., et al. (2019). Identification and pathogenicity assessment of Colletotrichum isolates causing bitter rot of apple fruit in Belgium. European Journal of Plant Pathology, 153, 253-269.

Grant, M., \& Lamb, C. (2006). Systemic immunity. Current Opinion in Plant Biology, 9, 414-420.

Grove, G. G., Dugan, F. M., \& Boal, R. J. (1992). Perennial canker of apple: Seasonal host susceptibility, spore production, and perennation of Cryptosporiopsis perennans in eastern Washington. Plant Disease, 76, 1109-1114.
Henriquez, J. L., Sugar, D., \& Spotts, R. A. (2004). Etiology of bull's eye rot of pear caused by Neofabraea spp. in Oregon, Washington, and California. Plant Disease, 88, 1134-1138.

Henriquez, J. L., Sugar, D., \& Spotts, R. A. (2006). Induction of cankers on pear tree branches by Neofabraea alba and $N$. perennans, and fungicide effects on conidial production on cankers. Plant Disease, 90, 481-486.

Henriquez, J. L., Sugar, D., \& Spotts, R. A. (2008). Effects of environmental factors and cultural practices on bull's eye rot of pear. Plant Disease, 92, 421-424.

Holb, I. (2006). Effect of six sanitation treatments on leaf litter density, ascospore production of Venturia inaequalis and scab incidence in integrated and organic apple orchards. European Journal of Plant Pathology, 115, 293-307.

Hortova, B., Novotny, D., \& Erban, T. (2014). Physiological characteristics and pathogenicity of eight Neofabraea isolates from apples in Czechia. European Journal of Horticultural Science, 79, 327-334.

Howard, R. J., \& Valent, B. (1996). Breaking and entering: Host penetration by the fungal rice blast pathogen Magnaporthe grisea. Annual Review of Microbiology, 50, 491-512.

Hsu, P. D., Lander, E. S., \& Zhang, F. (2014). Development and application of CRISPR-Cas9 for genome engineering. Cell, 157, 1262-1278.

Ippolito, A., \& Nigro, F. (2000). Impact of preharvest application of biological control agents on postharvest diseases of fresh fruit and vegetables. Crop Protection, 19, 715-723.

Jaillon, O., Aury, J. M., Noel, B., Policriti, A., Clepet, C., Casagrande, A., Choisne, N., Aubourg, S., Vitulo, N., Jubin, C., Vezzi, A., Legeai, F., Hugueney, P., Dasilva, C., Horner, D., Mica, E., Jublot, D., Poulain, J., Bruyère, C., Billault, A., Segurens, B., Gouyvenoux, M., Ugarte, E., Cattonaro, F., Anthouard, V., Vico, V., del Fabbro, C., Alaux, M., di Gaspero, G., Dumas, V., Felice, N., Paillard, S., Juman, I., Moroldo, M., Scalabrin, S., Canaguier, A., le Clainche, I., Malacrida, G., Durand, E., Pesole, G., Laucou, V., Chatelet, P., Merdinoglu, D., Delledonne, M., Pezzotti, M., Lecharny, A., Scarpelli, C., Artiguenave, F., Pè, M. E., Valle, G., Morgante, M., Caboche, M., Adam-Blondon, A. F., Weissenbach, J., Quétier, F., Wincker, P., \& French-Italian Public Consortium for Grapevine Genome Characterization. (2007). The grapevine genome sequence suggests ancestral hexaploidization in major angiosperm phyla. Nature, 449, 463-467.

Janisiewicz, W. J. (1987). Postharvest biological control of blue mold on apples. Phytopathology, 77, 481-485.

Janisiewicz, W. J. (1988). Biological control of diseases of fruits. In K. G. Mukerji \& K. L. Garg (Eds.), Biocontrol of plant diseases (pp. 153-165). Boca Raton: CRC Press.

Janisiewicz, W. J. (1996). Ecological diversity, niche overlap and coexistence of antagonists used in developing mixtures for biocontrol of postharvest diseases of apples. Phytopathology, $86,473-479$.

Janisiewicz, W. J. (1998). Biocontrol of postharvest diseases of temperate fruits. Challenges and opportunities. In G. J. Boland \& L. D. Kuykendall (Eds.), Plant- Microbe Interactions and Biological Control (pp. 171-198). New York: Marcel Dekker.

Janisiewicz, W. J. (2006). Microbial interactions affecting stemend blue mold decay of 'd'Anjou' pears. Postharvest Biology and Technology, 42, 217-221. 
Janisiewicz, W. J. (2008). Commercial applications and future prospects for the use of biological control after harvest. In: P. Bertolini (Ed.), Proceedings of the COST 924 International Congress on 'Novel Approaches for the Control of Postharvest Diseases and Disorders', Bologna, Italy, 3-5 May 2007, pp. 9-18.

Janisiewicz, W. J. (2013). Biological control of postharvest diseases: Hurdles, successes and prospects. Acta Horticulturae, 1001, 273-284.

Janisiewicz, W. J., \& Conway, W. S. (2010). Combining biological control with physical and chemical treatments to control fruit decays after harvest. Stewart Postharvest Review, 9, 1-16.

Janisiewicz, W. J., \& Jurick II, W. M. (2017). Sustainable approaches to control postharvest diseases of apples. In: Achieving sustainable cultivation of apples. Edited by Professor Kate Evans, Washington State University, USA. Published by Burleigh Dodds Science Publishing Limited. pp. 307-336.

Janisiewicz, W. J., \& Korsten, L. (2002). Biological control of postharvest diseases of fruits. Annual Review of Phytopathology, 40, 411-441.

Janisiewicz, W. J., Yourman, L., Roitman, J., \& Mahoney, N. (1991). Postharvest control of blue mold and gray mold of apples and pears by dip treatment with pyrrolnitrin, a metabolite of Pseudomonas cepacia. Plant Disease, 75, 490- 494.

Janisiewicz, W. J., Tworkoski, T. J., \& Sharer, C. (2000). Characterizing the mechanism of biological control of postharvest diseases on fruit with a simple method to study competition for nutrients. Phytopathology, 90, 1196-1200.

Janisiewicz, W. J., Saftner, R. A., Conway, W. S., \& Forsline, P. L. (2008). Preliminary evaluation of apple germplasm from Kazakhstan for resistance to postharvest blue mold in fruit caused by Penicillium expansum. HortScience, 43, 420-426.

Janisiewicz, W. J., Pimenta, R. S., \& Jurick II, W. M. (2011). A novel method for selecting antagonists against postharvest fruit decays originating from latent infections. Biological Control, 59, 384-389.

Janisiewicz, W. J., Nichols, B., Bauchan, G., Chao, T. C., \& Jurick II, W. M. (2016). Wound responses of wild apples suggest multiple resistance mechanism against blue mold decay. Postharvest Biology and Technology, 117, 132-140.

Jarvis, W. R. (1994). Latent infections in the pre- and post-harvest environment. Hortscience, 29, 749-751.

Jijakli, M. H., Grevesse, C., \& Lepoivre, P. (2001). Modes of action of biocontrol agents of postharvest diseases: Challenges and difficulties. Bulletin-OILB/SROP, 24, 317-318.

Jones, A. L., \& Aldwinckle, H. S. (1991). Bitter rot. In Compendium of apple and pear diseases (pp. 15-16). St. Paul: APS Press.

Jones, J. D. G., \& Dangl, J. L. (2006). The plant immune system. Nature, 444, 323-329.

Jurick II, W. M., Janisiewicz, W. J., Saftner, R. A., Vico, I., Gaskins, V. L., Park, E., et al. (2011). Identification of wild apple germplasm (Malus spp.) accessions with resistance to the postharvest decay pathogens Penicillium expansum and Colletotrichum acutatum. Plant Breeding, 130, 481-486.

Kim, Y. K., \& Xiao, C. L. (2008). Distribution and incidence of Sphaeropsis rot in apple in Washington state. Plant Disease, 92, 940-946.
Kleemann, J., Rincon-Rivera, L. J., Takahara, H., Neumann, U., Van Themaat, E. V. L., van der Does, H. C., Hacquard, S., Stüber, K., Will, I., \& Schmalenbach, W. (2012). Sequential delivery of host-induced virulence effectors by appressoria and intracellular hyphae of the phytopathogen Colletotrichum higginsianum. PLoS Pathogens, 8, e1002643.

Köhl, J., Wenneker, M., Groenenboom-de Haas, B. H., Anbergen, R., Goossen-van de Geijn, H. M., Lombaers-van der Plas, C. H., Pinto, F. A. M. F., \& Kastelein, P. (2018). Dynamics of post-harvest pathogens Neofabraea spp. and Cadophora spp. in plant residues in Dutch apple and pear orchards. Plant Pathology, 67, 1264-1277.

Köpcke, D. (2015). 1-Methylcyclopropene (1-MCP) and dynamic controlled atmosphere (DCA) applications under elevated storage temperatures: Effects on fruit quality of 'Elstar', 'Jonagol' and 'Gloster' apple (Malus domestica Borkh.). European Journal of Horticultural Science, 80, 25-32.

Korsten, L., De Villiers, E. E., Wehner, F. C., \& Kotze, J. M. (1994). A review of biological control of postharvest diseases of subtropical fruits. In B. R. Champ, E. Highley, \& G. L. Johnson (Eds.), Postharvest Handling of Tropical Fruits (pp. 172-185). Canberra: ACIAR.

Lagunas-Solar, M., Piña, C., MacDonald, J. D., \& Bolkan, L. (2006). Development of pulsed UV light processes for surface fungal disinfection of fresh fruits. Journal of Food Protection, 69, 376-384.

Lattanzio, V., Di Venere, D., Linsalata, V., Bertolini, P., Ippolito, A., \& Salerno, M. (2001). Low temperature metabolism of apple phenolics and quiescence of Phlyctaena vagabunda. Journal of Agricultural and Food Chemistry, 49, 5817-5821.

Latunde-Dada, A. O. (2001). Colletotrichum: Tales of forcible entry, stealth, transient confinement and breakout. Molecular Plant Pathology, 2, 187-198.

Laurens, F., Aranzana, M. J., Arus, P., Bassi, D., Bink, M., Bonany, J., et al. (2018). An integrated approach for increasing breeding efficiency in apple and peach in Europe. Horticulture Research, 5, 11.

Leistner, L. (2000). Basic aspects of food preservation by hurdle technology. International Journal of Food Microbiology, 55, 181-186.

Li, B., Zong, Y., Du, Z., Chen, Y., Zhang, Z., Qin, G., et al. (2015). Genomic characterization reveals insights into patulin biosynthesis and pathogenicity in Penicillium species. Molecular Plant-Microbe Interactions, 28, 635-647.

Lima, G., Ippolito, A., Nigro, F., \& Salerno, M. (1997). Effectiveness of Aureobasidium pullulans and Candida oleophila against postharvest strawberry rots. Postharvest Biology and Technology, 10, 169-178.

Llorente, I., Vilardell, A., \& Montesinos, E. (2006). Infection potential of Pleospora allii and evaluation of methods for reduction of the overwintering inoculum of brown spot of pear. Plant Disease, 90, 1511-1516.

Llorente, I., Vilardell, A., Vilardell, P., Pattori, E., Bugiani, R., Rossi, V., \& Montesinos, E. (2010). Control of brown spot of pear by reducing the overwintering inoculum through sanitation. European Journal of Plant Pathology, 128, 127-141.

Lopes, M. R., Klein, M. N., Ferraz, L. P., da Silva, A. C., \& Kupper, K. C. (2015). Saccharomyces cerevisiae: A novel and efficient biological control agent for Colletotrichum 
acutatum during pre-harvest. Microbiological Research, 175, 93-99.

Lorang, J., Kidarsa, T., Bradford, C. S., Gilbert, B., Curtis, M., Tzeng, S. C., Maier, C. S., \& Wolpert, T. J. (2012). Tricking the guard: Exploiting plant defense for disease susceptibility. Science, 338, 659-662.

Lysiak, G. (2013). The influence of harvest maturity and basic macroelement content in fruit on the incidence of diseases and disorders after storage of the 'Ligol 'apple cultivar. Folia Horticulturae, 25, 31-39.

Manteau, S., Abouna, S., Lambert, B., \& Legendre, L. (2003). Differential regulation by ambient $\mathrm{pH}$ of putative virulence factor secretion by the phytopathogenic fungus Botrytis cinerea. FEMS Microbiology Ecology, 43, 359-366.

Mari, M., Neri, F., \& Bertolini, P. (2011). Fruit postharvest disease control by plant bioactive compounds. In M. Rai \& M. Chikindas (Eds.), Natural antimicrobial in food safety and quality (pp. 242-260). Oxford: C.A.B. International.

Mari, M., Guidarelli, M., Martini, C., \& Spadoni, A. (2012). First report of Colletotrichum acutatum causing bitter rot on apple in Italy. Plant Disease, 96, 144.

Mari, M., Bautista-Baños, S., \& Sivakumar, D. (2016). Decay control in the postharvest system: Role of microbial and plant volatile organic compounds. Postharvest Biology and Technology, 122, 70-81.

Martínez-García, P. J., Parfitt, D. E., Bostock, R. M., FresnedoRamírez, J., Vazquez-Lobo, A., Ogundiwin, E. A., et al. (2013). Application of genomic and quantitative genetic tools to identify candidate resistance genes for brown rot resistance in peach. PLoS One, 8, e78634.

Massart, S., Martinez-Medina, M., \& Jijakli, M. H. (2015). Biological control in the microbiome era: Challenges and opportunities. Biological Control, 89, 98-108.

Maxin, P., \& Weber, R. W. S. (2011). Control of Phacidiopycnis washingtonensis storage rot of apples by hot-water treatments without the ethylene inhibitor 1-MCP. Journal of Plant Diseases and Protection, 118, 222-224.

Maxin, P., Weber, R. W. S., Pederson, H. L., \& Williams, M. (2012). Control of a wide range of storage rots in naturally infected apple by hot-water dipping and rinsing. Postharvest Biology and Technology, 70, 25-31.

Maxin, P., Williams, M., \& Weber, R. W. S. (2014). Control of fungal storage rots of apples by hot-water treatments: A northern European perspective. Erwerbs-Obstbau, 56, 25-34.

McArtney, S., Parker, M., Obermiller, J., \& Hoyt, T. (2011). Effects of 1-methylcyclopropene on firmness loss and the development of rots in apple fruit kept in farm markets or at elevated temperatures. HortTechnology, 21, 494-499.

Michalecka, M., Bryk, H., Poniatowska, A., \& Puławska, J. (2016). Identification of Neofabraea species causing bull's eye rot of apple in Poland and their direct detection in apple fruit using multiplex PCR. Plant Pathology, 65, 643-654.

Mikani, A., Etebarian, H. R., Sholberg, P. L., Gorman, D. T., Stokes, S., \& Alizadeh, A. (2008). Biological control of apple gray mold caused by Botrytis mali with Pseudomonas fluorescens strains. Postharvest Biology and Technology, $48,107-112$.

Misaghi, I. J. (1982). The role of pathogen-produced cell-wall degrading enzymes in pathogenesis. In I. J. Misaghi (Ed.),
Physiology and biochemistry of plant pathogen interactions (pp. 17-34). New York: Plenum Press.

Miyara, I., Shafran, H., Davidzon, M., Sherman, A., \& Prusky, D. (2010). pH regulation of ammonia secretion by Colletotrichum gloeosporioides and its effect on appressorium formation and pathogenicity. Molecular Plant-Microbe Interactions, 23, 304-316.

Moraga, J., Gomes, W., Pinedo, C., Cantoral, J. M., Hanson, J. R., Carbú, M., Garrido, C., Durán-Patrón, R., \& Collado, I. G. (2018). The current status on secondary metabolites produced by plant pathogenic Colletotrichum species. Phytochemistry Reviews. https://doi.org/10.1007/s11101018-9590-0.

Munda, A. (2014). First report of Colletotrichum fioriniae and C. godetiae causing apple rot in Slovenia. Plant Disease, 98, 1282.

Munir, M., Amsden, B., Dixon, E., Vaillancourt, L., \& Gauthier, N. A. W. (2016). Characterization of Colletotrichum species causing bitter rot of apple in Kentucky orchards. Plant Disease, 100, 2194-2203.

Neri, F., Mari, M., Brigati, S., \& Bertolini, P. (2009). Control of Neofabraea alba by plant volatile compounds and hot water. Postharvest Biology and Technology, 51, 425-430.

Niem, J., Miyara, I., Ettedgui, Y., Reuveni, M., Flaishman, M., \& Prusky, D. (2007). Core rot development in red delicious apples is affected by susceptibility of the seed locule to Alternaria alternata colonization. Phytopathology, 97, 1415-1421.

Nigro, F., Ippolito, A., \& Lima, G. (1998). Use of UV-C light to reduce Botrytis storage rot of table grapes. Postharvest Biology and Technology, 13, 171-181.

Nodet, P., Baroncelli, R., Faugère, D., \& Le Floch, G. (2016). First report of apple bitter rot caused by Colletotrichum fioriniae in Brittany, France. Plant Disease, 100, 1497.

Norelli, J., Wisniewski, M., \& Droby, S. (2014). Identification of a QTL for postharvest disease resistance to Penicillium expansum in Malus sieversii. Acta Horticulturae, 1053, 199-203.

Nürnberger, T., Brunner, F., Kemmerling, B., \& Piater, L. (2004). Innate immunity in plants and animals, striking similarities and obvious differences. Immunological Reviews, 198, 249-266.

Pacheco, I., Bassi, D., Eduardo, I., Ciacciulli, A., Pirona, R., Rossini, L., \& Vecchietti, A. (2014). QTL mapping for brown rot (Monilinia fructigena) resistance in an intraspecific peach (Prunus persica L. Batsch) F1 progeny. Tree Genetics \& Genomes, 10, 1223-1242.

Palou, L., Ali, A., Fallik, E., \& Romanazzi, G. (2016). GRAS, plant and animal-derived compounds as alternatives to conventional fungicides for the control of postharvest diseases of fresh horticultural produce. Postharvest Biology and Technology, 122, 41-52.

Patocchi, A., Walser, M., Tartarini, S., Broggini, G. A., Gennari, F., Sansavini, S., \& Gessler, C. (2005). Identification by genome scanning approach (GSA) of a microsatellite tightly associated with the apple scab resistance gene $\mathrm{Vm}$. Genome, 48, 630-636.

Paynter, V. A., \& Jen, J. J. (1975). Characterization of pectic enzymes from Monilinia fructicola. Biochemical Physiological Pflanzen, 167, 219-231. 
Peres, N. A., Timmer, L. W., Adaskaveg, J. E., \& Correll, J. C. (2005). Lifestyles of Colletotrichum acutatum. Plant Disease, 89, 784-796.

Pešicová, K., Kolařík, M., Hortová, B., \& Novotný, D. (2017). Diversity and identification of Neofabraea species causing bull's eye rot in the Czech Republic. European Journal of Plant Pathology, 147, 683-693.

Phoulivong, S., Cai, L., Chen, H., McKenzie, E. H. C., Abdelsalam, K., Chukeatirote, E., \& Hyde, K. D. (2010). Colletotrichum gloeosporioides is not a common pathogen on tropical fruits. Fungal Diversity, 44, 33-43.

Pitzschke, A., Forzani, C., \& Hirt, H. (2006). Reactive oxygen species signaling in plants. Antioxidants \& Redox Signaling, 8, 1757-1764.

Prins, T. W., Tudzynski, P., von Tiedemann, A., Tudzynski, B., Ten Have, A., Hansen, M. E., et al. (2000). Infection strategies of Botrytis cinerea and related necrotrophic pathogens. In J. W. Kronstad (Ed.), Fungal Pathology (pp. 33-65). Dordrecht: Kluwer Acad.

Prusky, D. (1996). Pathogen quiescence in postharvest diseases. Annual Review of Phytopathology, 34, 413-434.

Prusky, D., \& Lichter, A. (2007). Activation of quiescent infections by postharvest pathogens during transition from the biotrophic to the necrotrophic stage. FEMS Microbiology Letters, 268, 1-8.

Prusky, D., Benarie, R., \& Guelfatreich, S. (1981). Etiology and histology of Alternaria rot of persimmon fruits. Phytopathology, 71, 1124-1128.

Prusky, D., Mcevoy, J. L., Leverentz, B., \& Conway, W. S. (2001). Local modulation of host $\mathrm{pH}$ by Colletotrichum species as a mechanism to increase virulence. Molecular Plant-Microbe Interactions, 14, 1105-1113.

Prusky, D., Alkan, N., Mengiste, T., \& Fluhr, R. (2013). Quiescent and necrotrophic lifestyle choice during postharvest disease development. Annual Review of Phytopathology, 51, 155-176.

Robert-Seilaniantz, A., MacLean, D., Jikumaru, Y., Hill, L., Yamaguchi, S., Kamiya, Y., \& Jones, J. D. (2011). The microRNA miR393 re-directs secondary metabolite biosynthesis away from camalexin and towards glucosinolates. The Plant Journal, 67, 218-231.

Romanazzi, G., Sanzani, S. M., Bic, Y., Tian, S., Martínez, P. G., \& Alkan, N. (2016a). Induced resistance to control postharvest decay of fruit and vegetables. Postharvest Biology and Technology, 122, 82-94.

Romanazzi, G., Smilanick, J. L., Feliziani, E., \& Droby, S. (2016b). Integrated management of postharvest gray mold on fruit crops. Postharvest Biology and Technology, 113, 69-76.

Rossi, V., \& Pattori, E. (2009). Inoculum reduction of Stemphylium vesicarium, the causal agent of brown spot of pear, through application of Trichoderma-based products. Biological Control, 49, 52-57.

Rovenich, H., Boshoven, J. C., \& Thomma, B. P. H. J. (2014). Filamentous pathogen effector functions: Of pathogens, hosts and microbiomes. Current Opinion in Plant Biology, 20, 96-103.

Sever, Z., Ivić, D., Kos, T., \& Miličević, T. (2012). Identification of Fusarium species isolated from stored apple fruit in Croatia. Archives of Industrial Hygiene and Toxicology, 63, 463-470.
Sharma, R. R., Singh, D., \& Singh, R. (2009). Biological control of postharvest diseases of fruits and vegetables by microbial antagonists: A review. Biological Control, 50, 205-221.

Sharples, R. O. (1985). The influence of preharvest conditions on the quality of stored fruits. Acta Horticulturae, 157, 93-104.

Shi, Y., Correll, J. C., Guerber, J. C., \& Rom, C. R. (1996). Frequency of Colletotrichum species causing bitter rot of apple in the southeastern United States. Plant Disease, 80, 692-696.

Sivakumar, D., \& Bautista-Baños, S. (2014). A review on the use of essential oils for postharvest decay control and maintenance of fruit quality during storage. Crop Protection, 64, 27-37.

Snowdon, A. L. (1990). Pome fruits. In A. L. Snowdon (Ed.), A colour atlas of post-harvest diseases and disorders of fruits and vegetables, General introduction and fruits (Vol. 1, pp. 170-218). London: Wolfe Scientific Ltd.

Soto-Alvear, S., Lolas, M., Rosales, I. M., Chávez, E. R., \& Latorre, B. A. (2013). Characterization of the bull's eye rot of apple in Chile. Plant Disease, 97, 485-490.

Spolti, P., Valdebenito-Sanhueza, R. M., Laranjeira, F. F., \& Del Ponte, E. M. (2012). Comparative spatial analysis of the sooty blotch/flyspeck disease complex, bull's eye and bitter rots of apples. Plant Pathology, 61, 271-280.

Spotts, R. A. (1990). Bull's-eye rot. In A. L. Jones \& H. S. Aldwinckle (Eds.), Compendium of apple and pear diseases (p. 56). St. Paul: APS Press.

Spotts, R. A., Sholberg, P. L., Randall, P., Serdani, M., \& Chen, P. M. (2007). Effects of 1-MCP and hexanal on decay of d'Anjou pear fruit in long-term cold storage. Postharvest Biology and Technology, 44, 101-106.

Spotts, R. A., Seifert, K. A., Wallis, Sugar, D., Xiao, C. L., Serdani, M., \& Henriquez, J. L. (2009). Description of Cryptosporiopsis kienholzii and species profiles of Neofabraea in major pome fruit growing districts in the Pacific Northwest USA. Mycological Research, 113, 1301-1311.

Stevens, C., Wilson, C. L., Lu, J. Y., Khan, V. A., Chalutz, E., Droby, S., et al. (1996). Plant hormesis induced by ultraviolet light-C for controlling postharvest diseases of tree fruits. Crop Protection, 15, 129-134.

Sugar, D., \& Spotts, R. A. (1992). Sources of inoculum of Phialophora malorum, causal agent of side rot of pear. Phytopathology, 82, 735-738.

Sutton, T. B. (2014). Bitter rot. In T. B. Sutton, H. S. Aldwinckle, A. M. Agnello, \& J. F. Walgenbach (Eds.), Compendium of apple and pear diseases and pests (2nd ed., pp. 20-21). St. Paul: The American Phytopathological Society.

Tahir, I., Nybom, H., Ahmadi-Afzadi, M., Roen, K., Sehic, J., \& Roen, D. (2015). Susceptibility to blue mold caused by Penicillium expansum in apple cultivars adapted to a cool climate. European Journal of Horticultural Science, 80, 117-127.

Teixidó, N., Usall, J., \& Vinas, I. (1999). Efficacy of preharvest and postharvest Candida sake biocontrol treatments to prevent blue mold on apples during storage. International Journal of Food Microbiology, 50, 203-210.

Terry, L. A., \& Joyce, D. C. (2004). Elicitors of induced disease resistance in postharvest horticultural crops: A brief review. Postharvest Biology and Technology, 32, 1-13. 
Thewes, F. R., Both, V., Brackmann, A., Anderson Weber, A., \& Anese, R. O. (2015). Dynamic controlled atmosphere and ultralow oxygen storage on 'Gala' mutants quality maintenance. Food Chemistry, 188, 62-70.

Tian, S., Torres, R., Ballester, A.-R., Li, B., Vilanova, L., \& González-Candelas, L. (2016). Molecular aspects in pathogen-fruit interactions: Virulence and resistance. Postharvest Biology and Technology, 122, 11-21.

Turketti, S. S., Curry, E., \& Lötze, E. (2012). Role of lenticel morphology, frequency and density on incidence of lenticel breakdown in 'gala' apples. Scientia Horticulturae, 138, 90-95.

Usall, J., Teixido, N., Torres, R., Ochoa de Eribe, X., \& Vinas, I. (2001). Pilot tests of Candida sake (CPA-1) applications to control postharvest blue mold on apple fruit. Postharvest Biology and Technology, 21, 147-156.

Usall, J., Casals, C., Sisquella, M., Palou, L., \& De Cal, A. (2015). Alternative technologies to control postharvest diseases of stone fruits. Stewart Postharvest Review, 11, 1-6.

Usall, J., Ippolito, A., Sisquell, M., \& Neri, F. (2016). Physical treatments to control postharvest diseases of fresh fruits and vegetables. Postharvest Biology and Technology, 122, 30-40.

Valero, A., Begum, M., Leong, S. L., Hocking, A. D., Ramos, A. J., Sanchis, V., \& Marín, S. (2007). Effect of germicidal UVC light on fungi isolated from grapes and raisins. Letters in Applied Microbiology, 45, 238-243.

Van Loon, L. C., Rep, M., \& Pieterse, C. M. J. (2006). Significance of inducible defence related proteins in infected plants. Annual Review of Phytopathology, 44, 135-162.

Van Schaik, A., \& Verschoor, J. (2003). CA-storage: Technology, application and research. State of the art in the Netherlands. Acta Horticulturae, 600, 181-187.

Velasco, R., Zharkikh, A., Affourtit, J., Dhingra, A., Cestaro, A., Kalyanaraman, A., Fontana, P., Bhatnagar, S. K., Troggio, M., Pruss, D., Salvi, S., Pindo, M., Baldi, P., Castelletti, S., Cavaiuolo, M., Coppola, G., Costa, F., Cova, V., Dal Ri, A., Goremykin, V., Komjanc, M., Longhi, S., Magnago, P., Malacarne, G., Malnoy, M., Micheletti, D., Moretto, M., Perazzolli, M., Si-Ammour, A., Vezzulli, S., Zini, E., Eldredge, G., Fitzgerald, L. M., Gutin, N., Lanchbury, J., Macalma, T., Mitchell, J. T., Reid, J., Wardell, B., Kodira, C., Chen, Z., Desany, B., Niazi, F., Palmer, M., Koepke, T., Jiwan, D., Schaeffer, S., Krishnan, V., Wu, C., Chu, V. T., King, S. T., Vick, J., Tao, Q., Mraz, A., Stormo, A., Stormo, K., Bogden, R., Ederle, D., Stella, A., Vecchietti, A., Kater, M. M., Masiero, S., Lasserre, P., Lespinasse, Y., Allan, A. C., Bus, V., Chagné, D., Crowhurst, R. N., Gleave, A. P., Lavezzo, E., Fawcett, J. A., Proost, S., Rouzé, P., Sterck, L., Toppo, S., Lazzari, B., Hellens, R. P., Durel, C. E., Gutin, A., Bumgarner, R. E., Gardiner, S. E., Skolnick, M., Egholm, M., van de Peer, Y., Salamini, F., \& Viola, R. (2010). The genome of the domesticated apple (Malus x domestica Borkh). Nature Genetics, 42, 833-839.

Velho, A. C., Alaniz, S., Casanova, L., Mondino, P., \& Stadnik, M. J. (2015). New insights into the characterization of Colletotrichum species associated with apple diseases in southern Brazil and Uruguay. Fungal Biology, 119, 229-244.

Verde, I., Abbott, A. G., Scalabrin, S., Jung, S., Shu, S., Marroni, F., et al. (2013). The high-quality draft genome of peach (Prunus persica) identifies unique patterns of genetic diversity, domestication and genome evolution. Nature Genetics, 45, 487-494.

Verhoeff, K. (1974). Latent infections by fungi. Annual Review of Phytopathology, 12, 99-110.

Verkley, G. J. (1999). A monograph of the genus Pezicula and its anamorphs. Studies in Mycology, 44, 1-176.

Vilanova, L., Wisniewski, M., Norelli, J., Viñas, I., Torres, R., Usall, J., Phillips, J., Droby, S., \& Teixido, N. (2014). Transcriptomic profiling of apple in response to inoculation with a pathogen (Penicillium expansum) and a non-pathogen (Penicillium digitatum). Plant Molecular Biology Reporter, 32, 566-583.

Volk, G. M., Chao, C. T., Norelli, J., Brown, S. K., Fazio, G., Peace, C., et al. (2015). The vulnerability of US apple (Malus) genetic resources. Genetic Resources and Crop Evolution, 62, 765-794.

Weber, R. W. S. (2011). Phacidiopycnis washingtonensis, cause of a new storage rot of apples in northern Europe. Journal of Phytopathology, 159, 682-686.

Weber, R. W. S. (2012). Mikroskopische Methode zum Nachweis pathogener Pilze aus Fruchtmumien von Äpfeln. [a microscopy-based method for screening apple fruit mummies for pathogenic fungi.]. Erwerbs-Obstbau, 54, 171-176.

Weber, R. W. S., \& Dralle, N. (2013). Fungi associated with blossom-end rot of apples in Germany. European Journal of Horticultural Science, 78, 97-105.

Weber, R. W. S., \& Palm, G. (2010). Resistance against storage rot fungi Neofabraea perennans, N. alba, Glomerella acutata and Neonectria galligena against thiophanate-methyl in northern German apple production. Journal of Plant Diseases and Protection, 11, 185-191.

Weiberg, A., Wang, M., Lin, F.-M., Zhao, H., Zhang, Z., Kaloshian, I., Huang, H.-D., \& Jin, H. (2013). Fungal small RNAs suppress plant immunity by hijacking host RNA interference pathways. Science, 342, 118-123.

Wenneker, M., Joosten, N., \& Luckerhoff, L. (2013). Use of (pulsed) UV-C light to control spore germination and mycelial growth of storage diseases causing fungi, and effect on control of storage rot in apples and pears. IOBC-WPRS Bulletin, 91, 389-393.

Wenneker, M., Pham, K. T. K., Lemmers, M. E. C., de Boer, F. A., van der Lans, A. M., van Leeuwen, P. J., \& Hollinger, T. C. (2016a). First report of Colletotrichum godetiae causing bitter rot on 'Golden delicious' apples in the Netherlands. Plant Disease, 100, 218.

Wenneker, M., Pham, K. T. K., Lemmers, M. E. C., de Boer, F. A., van der Lans, A. M., van Leeuwen, P. J., Hollinger, T. C., \& Thomma, B. P. H. J. (2016b). First report of Fusarium avenaceum causing wet core rot of 'Elstar' apples in the Netherlands. Plant Disease, 100, 1501.

Wenneker, M., Pham, K. T. K., Lemmers, M. E. C., de Boer, F. A., van der Lans, A. M., van Leeuwen, P. J., Hollinger, T. C., \& Thomma, B. P. H. J. (2016c). First report of Neonectria candida causing postharvest decay on 'conference' pears in the Netherlands. Plant Disease, 100, 1787.

Wenneker, M., Pham, K. T. K., Lemmers, M. E. C., de Boer, F. A., van der Lans, A. M., van Leeuwen, P. J., Hollinger, T. C., \& Thomma, B. P. H. J. (2016d). First report of Fusarium avenaceum causing postharvest decay on 'conference' pears in the Netherlands. Plant Disease, 100, 1950. 
Wenneker, M., Pham, K. T., Lemmers, M. E. C., de Boer, F. A., van Leeuwen, P. J., Hollinger, T. C., Groenenboom-de Haas, B. H., \& Köhl, J. (2016e). First report of Cadophora luteoolivacea causing side rot on 'conference' pears in the Netherlands. Plant Disease, 100, 2162.

Wenneker, M., Pham, K. T. K., Boekhoudt, L. C., de Boer, F. A., van Leeuwen, P. J., Hollinger, T. C., \& Thomma, B. P. H. J. (2017a). First report of Truncatella angustata causing postharvest rot on 'topaz' apples in the Netherlands. Plant Disease, 101, 508.

Wenneker, M., Pham, K. T. K., Boekhoudt, L. C., de Boer, F. A., van Leeuwen, P. J., Hollinger, T. C., \& Thomma, B. P. H. J. (2017b). First report of Neofabraea kienholzii causing bull's eye rot on pear (Pyrus communis) in the Netherlands. Plant Disease, 101, 634.

Wenneker, M., Pham, K. T. K., Lemmers, M. E. C., de Boer, F. A., van Leeuwen, P. J., Hollinger, T. C., van de Geijn, F. G., \& Thomma, B. P. H. J. (2017c). Fibulorhizoctonia psychrophila is the causal agent of lenticel spot on apple and pear fruit in the Netherlands. European Journal of Plant Pathology, 148, 213-217.

Wilson, C. L., \& Wisniewski, M. E. (1989). Biological control of postharvest diseases of fruits and vegetables: An emerging technology. Annual Review of Phytopathology, 27, 425-441.

Wiseman, M. S., Kim, Y. K., Dugan, F. M., Rogers, J. D., \& Xiao, C. (2016). A new postharvest fruit rot in apple and pear caused by Phacidium lacerum. Plant Disease, 100, 32-39.

Wisniewski, M. E., Droby, S., Chalutz, E., \& Eilam, Y. (1995). Effect of $\mathrm{Ca} 2+$ and $\mathrm{Mg} 2+$ on Botrytis cinerea and Penicillium expansum in vitro and on the biocontrol activity of Candida oleophilla. Plant Pathology, 44, 1016-1024.

Wisniewski, M., Droby, S., Norelli, J., Jia Liu, J., \& Schena, L. (2016a). Alternative management technologies for postharvest disease control: The journey from simplicity to complexity. Postharvest Biology and Technology, 122, 3-10.

Wisniewski, M., Norelli, J., Droby, S., Ballester, A.-R., Abdelfattah, A., \& Levin, E. (2016b). Genomic tools for developing markers for postharvest disease resistance in Rosaceae fruit crops. Acta Horticulturae, 1144, 7-16.

Xiao, C. L., \& Kim, Y. K. (2008). Postharvest fruit rot in apples caused by Botrytis cinerea, Phacidiopycnis washingtonensis and Sphaeropsis pyriputrescens. Plant Health Progress, 113.

Xu, Q., Chen, L.-L., Ruan, X., Chen, D., Zhu, A., Chen, C., Bertrand, D., Jiao, W. B., Hao, B. H., Lyon, M. P., Chen, J., Gao, S., Xing, F., Lan, H., Chang, J. W., Ge, X., Lei, Y., Hu, Q., Miao, Y., Wang, L., Xiao, S., Biswas, M. K., Zeng, W., Guo, F., Cao, H., Yang, X., Xu, X. W., Cheng, Y. J., Xu, J., Liu, J. H., Luo, O. J., Tang, Z., Guo, W. W., Kuang, H., Zhang, H. Y., Roose, M. L., Nagarajan, N., Deng, X. X., \& Ruan, Y. (2013). The draft genome of sweet orange (Citrus sinensis). Nature Genetics, 45, 59-66.

Yakoby, N., Kobiler, I., Dinoor, A., \& Prusky, D. (2000). pH regulation of pectate lyase secretion modulates the attack of Colletotrichum gloeosporioides on avocado fruits. Applied and Environmental Microbiology, 66, 1026-1030.

Yokosawa, S., Eguchi, N., Kondo, K., \& Sato, T. (2017). Phylogenetic relationship and fungicide sensitivity of members of the Colletotrichum gloeosporioides species complex from apple. Journal of General Plant Pathology, 83, 291-298.

Zhang, L., Kars, I., Essenstam, B., Liebrand, T. W. H., Wagemakers, L., Elberse, J., et al. (2014). Fungal endopolygalacturonases are recognized as microbeassociated molecular patterns by the Arabidopsis receptorlike protein responsiveness to Botrytis polygalacturonases. Plant Physiology, 164, 352-364. 